\title{
Generációk és az infokommunikációs eszközök használata egy általános iskolában végzett mikrokutatás tükrében
}

Generations and the use of infocommunication devices in the mirror of a micro research carried out in a primary school

\section{SZARVASNÉ TOMPA ZSUZSANNA}

\begin{abstract}
Szarvasné Tompa Zsuzsanna: hallgató az iskolai és óvodai szociális segítő szakirányú továbbképzésen; Pécsi Tudományegyetem, Bölcsészet- és Társadalomtudományi Kar, Társadalmi Kapcsolatok Intézete, Közösségi és Szociális Tanulmányok Tanszék; Gyermeklánc Óvoda és Bölcsőde Családsegítő és Gyermekjóléti Központ (Jánoshalma); zstompa@gmail.com
\end{abstract}

Zsuzsanna Szarvasné Tompa: Student in School Social Work (Non-degree Postgraduate Specialization); University of Pécs, Faculty of Humanities and Social Sciences, Institute of Social Relations, Department of Community and Social Studies; Gyermeklánc Kindergarten, Nursery, Family Support and Child Welfare Centre (Jánoshalma); zstompa@gmail.com

\begin{abstract}
Absztrakt
Napjaink társadalomtudományi kutatásainak egyik fontos témája az információs és kommunikációs technológiák (a továbbiakban: IKT) használatában mutatkozó generációs különbségek. Életünk minden területét behálózza az internet, és a hozzá kapcsolódó eszközök használata. A digitális oktatásra való átállás fontossága, ezáltal az IKT-eszközök használata felerősödött a COVID-19 járvány okozta helyzetben. Tanulmányomban ismertetek néhány, az IKT-eszközök használatához kapcsolódó fogalmat, illetve bemutatom egy általános iskolában végzett kérdőíves vizsgálatom fontosabb eredményeit.
\end{abstract}

Kulcsszavak: generációk, IKT-eszközök, kommunikáció, COVID-19, digitális kompetencia

\begin{abstract}
Generational differences in the use of information and communications technologies (ICT) are a key theme in contemporary social research. Internet use and the application of its related devices have an impact on all the areas of life. The Covid-19 pandemic facilitated rapid transition to digital education and to the use of ICT devices. In the current article, I comment on some concepts related to ICT use and on some results of a survey that I have conducted in a primary school.
\end{abstract}

Keywords: generations, ICT-devices, communication, COVID-19, digital competence

\section{Bevezető}

Tanulmányom témája napjaink egyik aktuális kérdése, a generációk közti kommunikációs eltérések, illetve ezen belül az, hogy miként, milyen mértékben használják az IKT-eszközöket. Ezekre a különbségekre a megváltozott körülmények, mint a technológia fejlettsége, vagy a 
média, szintén nagy hatással van. Az élet számos területén megfigyelhető, hogy a személyes kommunikáció egyre inkább kezd a háttrébe szorulni. Írásomban egyrészt a témával kapcsolatos alapfogalmakat tárgyalom, másrészt empirikus kutatásom eredményeit mutatom be. A kutatás során az eszközhasználat sajátosságaival foglalkoztam, a felhasználói szokásokat kérdőíves formában, valamint fókuszcsoportos interjú során vizsgáltam. A témát 2020 márciusa tette igazán aktuálissá, amikor az új koronavírus-betegség sokkhatásként érkezett az életünkbe.

\section{COVID-19-pandémia}

Az idei évünk nagy kihívása, a COVID-19, vagyis az új koronavírus (SARS-CoV-2), melyet Kínában azonosítottak 2019 végén. Mára szinte az egész világban okoz megbetegedéseket. Az általa okozott betegséget COVID-19-nek (COVID: coronavirus disease - koronavírus okozta megbetegedés 2019) nevezik. A COVID-19 járvány miatt világszerte ideiglenesen iskolabezárásokra került sor. Magyarországon 2020. március 11-én rendelte el a Kormány az egyetemek látogatási tilalmát, míg 13-án a köznevelésben is a digitális távoktatásra való átállásról döntött (Infojegyzet, 2020).

\section{Esélyegyenlőség}

A világméretű járvány, mely Magyarországot sem kerülte el, nem csak járványügyi intézkedéseket hozott magával, de felszínre kerültek az esélyegyenlőség kérdései is. A demokratikus jogállamokban alapvető követelmény az esélyegyenlöség, „egy olyan elv, amelynek az alkotmányban és minden jogszabályban fontos helye van" (Varga, 2013: 11). Az esélyegyenlőség területén belül az egyik legmarkánsabb problémát a társadalmi javakhoz való hozzáférés egyenlőtlensége jelenti. A demokratikus államok ugyanakkor ezeket az egyenlőtlenségeket igyekeznek kiegyenlíteni, ami kettőséget eredményez a szabadság szempontjából; hiszen szükségessé teszi a szabadság korlátozását, másrészt a társadalmi egyenlöségröl csak akkor beszélhetünk, ha a szabadság is megvalósul (Varga, 2013). „A teljes esélyegyenlöséget megvalósitó egyenlő hozzáférés első kérdése az, hogy a szegényebb, szociálisan deprivált rétegek - éppen lakóhelyi elhelyezkedésük, illetve az ország településszerkezetének sajátosságai okán - azonos mértékben férnek-e hozzá a szolgáltatásokhoz." (Babusik, 2003: 10)

További kérdéseket vet fel az esélyegyenlőség kapcsán, hogy a digitális tanrendre történő hirtelen átállás milyen hátrányokat okoz vagy okozhat az egyébként is leszakadóban lévő társadalmi rétegek helyzetében, amikor a tananyag átadása távolról, infokommunikációs eszközök használatával történik. A COVID-19-helyzet következtében fontos képet kapni arról, hogy a hozzáférésben korlátozott, hátrányos helyzetű tanulók milyen mértékben kerülnek még hátrányosabb helyzetbe, hiszen ezekben a családokban korábban is kihívást jelentett alkalmazkodni az iskolai szabályokhoz. A dolgozat utóélete, hogy a kialakult helyzet következtében figyelemmel kísértem, hogyan alakul a digitális oktatás az általam vizsgált iskolában. 63 fö tanulónak semmilyen lehetősége nem volt a digitális oktatásba bekapcsolódni a 253 fös iskolában. 


\section{Generációk}

A téma szempontjából fontos tisztázni a generációk fogalmát. A hagyományos meghatározás Komár (2017) szerint: a generáció „a szülők és utódaik születése közötti átlagos időintervallumot" jelöli, mely 20-25 évet ölel fel (Komár, 2017: 8-9).

A társadalmigeneráció-elméletek egyik jelentős alakja Mannheim Károly (1928), aki úgy gondolta, hogy a generációk tagjai között valamilyen rendszerösszefüggés van. Ahhoz, hogy egy társadalmi csoportról azt lehessen mondani, hogy egy generációhoz tartozik, három dolog szükséges: nagyjából egy időben születtek, nagyjából egy történelmi időszak hat rájuk, nagyjából ugyanabban a szociokulturális környezetben nőttek fel. „Mannheim szerint a gyors társadalmi változások során sokkal könnyebben alakulnak ki jól meghatározható generációk, és egy-egy nagyobb generáción belül léteznek kisebb, úgynevezett szubgenerációk." (Buda, 2019: 121-122).

Az elmúlt néhány évtizedben a digitális forradalom nagy sebességgel alakítja az életünket, a gyors iramú fejlődés pedig, hatalmas kommunikációs szakadékot eredményez a generációk között. A pedagógusszakma szerint ez a szakadék már nem csak a családban érzékelhető, de az iskolában is észrevehető, ami megnyilvánul mind a nevelési, mind pedig az oktatási kérdésekben (Komár, 2017).

A hagyományosnak tekinthető generációs elméletek mellett természetesen kialakult több olyan kategorizálás is, mely az egyes csoportok digitális világhoz történő viszonyulásán alapul. Az egyik legismertebb felosztás ezek közül Kulcsár Zsolt 2008-ban írt (majd 2014-ben átdolgozott) Az integratív e-learning felé című e-bookjában jelent meg (Buda, 2019):

$$
\begin{array}{ll}
\text { - } & 1925-1945-\text { Veteránok } \\
\text { - } & 1946-1964-\text { Bébibumm } \\
\text { - } & 1965-1979-\text { X generáció } \\
\text { - } & 1980-1995-\text { Y generáció } \\
\text { - } & 1996-\quad-Z \text { generáció }
\end{array}
$$

A bébibumm generáció tagjai középkorú felnőttként találkoztak a számítógépekkel, ennek következtében bizonyos szempontból kényszerpályán mozogtak, kénytelenek voltak elsajátítani a számítógépek használatát, azonban az új eszközök, megoldások, nem váltak életük szerves részévé.

Az X generáció tagjai tinédzserként vagy fiatal felnőttként kerültek kapcsolatba a digitális világgal, így munkájukat jelentősen befolyásolja az új technológia, és azt magánemberként is egyre gyakrabban, egyre szélesebb felhasználási körben alkalmazzák.

Az Y generáció viszont már gyermekként találkozott a számítógéppel, sokszor az internettel is. Ennek következtében ezt a generációt nevezhetjük a digitális nemzedék első hullámának. Munkájukba és életvitelükbe szervesen beépült az új technológia. A Z és Alfa generáció tagjai pedig szinte csak azt a világot ismerik. Fiatal koruktól idejük jelentős részét online töltik, nemegyszer ,a közösségi oldalhoz kapcsolódva, kezükben telefonnal alszanak el és kelnek fel”' (Zombainé, 2015: 20).

\section{Kommunikáció}

Felmerül a kérdés, hogy mi teszi szükségessé, hogy kiemelt helyet kapjon az iskolában a kommunikáció témája és problémaköre. 
A Magyar Larousse Enciklopédiában a következő jelentésekkel találkozhatunk: „,kommunikáció lat. 1. tájékoztatás, (hír)közlés 2. hír információk közlése v. cseréje valamilyen erre szolgáló eszköz, ill. jelrendszer (nyelv, gesztusok stb.) útján 3. ritk. közlemény 4. rég. összeköttetés, közlekedés, érintkezés” (Magyar Larousse Enciklopédia 2. kötet, 1979-1992: 493). A fentiekből következik, hogy kommunikáció minden, melyben információ továbbítása történik. Ez kiegészül az információk, gondolatok, érzelmek továbbításával, vagyis a kommunikáció segítségével, megfelelő szimbólumok, szimbólumrendszerek használata mellett az emberek információk, érzések, gondolatok közös értelmezésére törekszenek.

A kommunikáció során említést kell tennünk arról, hogy milyen kapcsolatban áll a nyelvi változás a technika fejlödésével? Hogyan alakul át az emberi gondolkodás ezen eszközök hatására? Valóban el fog veszni idővel a kézírás? Ennek kapcsán jelentős Marschall McLuhan (1964) munkássága, melynek középpontjában a technológiai változások álltak. A technológiai determinizmus munkájában kulcskérdés, hogy vajon mennyiben változtatják meg a kommunikáló egyén lehetőségeit a technológiai változások, és ezzel egyidejűleg pedig milyen forradalmi változások történnek a nyilvánosság alapjául szolgáló médiacsatornákban. McLuhan a hatvanas évek elején dolgozta ki elméletét, melynek lényege, hogy a technológia határozza meg az emberek mindennapjait. Az emberi élet minden színterére hatással van a technikai fejlődés, legyen az család, munka, iskola, szórakozás. Minden médium az emberi érzékelés kiterjesztése, ezért a médiumok, ahogy változnak, átformálják egyben az emberi kultúrát is (Varga, 1999).

\section{Kompetenciák}

„A kompetenciát (Nagy József nyomán) olyan - ismereteket, készségeket, képességeket, személyiségjegyeket és attitüdöket tartalmazó - komplex rendszernek tekinthetjük, amely képessé, kompetenssé teszi birtoklóját arra, hogy különbözö helyzetekben, összetett, életszerü feladatok megoldásában eredményesen, hatékonyan cselekedjék." (Klenovitsné, 2011)

Az egész életen át tartó tanuláshoz szükséges kulcskompetenciák európai referenciakerete szerint a kulcskompetencia az ismeretek, készségek és attitüdök transzferábilis, többfunkciós egysége, amellyel mindenkinek rendelkeznie kell ahhoz, hogy személyiségét kiteljesíthesse és fejleszthesse, be tudjon illeszkedni a társadalomba és foglalkoztatható legyen. A kulcskompetenciákat a kötelező oktatás, illetve képzés időszaka alatt kell elsajátítani. A későbbiekben az egész életen át tartó tanulás során mindenféle tanulás alapját ezek a kompetenciák képezik (Európai Tanács, 2004). Az Európai Unió referenciakerete (2006) alapján 8 kulcskompetencia került meghatározásra, melyek a következők: 1. anyanyelvi kommunikáció, 2. idegen nyelvi kommunikáció, 3. matematikai, természettudományi és technológiai kompetenciák, 4. digitális kompetenciák, 5. a tanulás tanulása, 6. személyközi és állampolgári kompetenciák, 7. vállalkozói kompetenciák, 8. kulturális kompetenciák. Ma kiemelkedően fontos a digitális kompetencia. Az alacsony vagy nem megfelelő végzettségü személyek azonban az élet számos területén hátrányos helyzetben vannak (OFI, 2009).

A digitális esélyegyenlőtlenség elvileg kiegyenlíthető, illetve kívánatos lenne ez a kiegyenlítődés, azonban jellemző, hogy a hátrányos helyzetü csoportok tagjai több szempontból is jelentősen rosszabb helyzetben vannak a társadalom átlagánál. Kérdés, hogy az alapvető hiányokkal küzdve képesek-e az információs társadalomba való bekapcsolódásra, amely eszköz lehet a hátrányok csökkentésére: az izoláció és a kirekesztés oldására, tőkehiányaik csökkentésére. A csatlakozás ugyan nem csodaszer, ami a hátrányos helyzetet megszünteti, de 
egy-egy dimenzió mentén hozhat javulást. A számítástechnikai eszközök, az internet nyújtotta szolgáltatások, készségfejlesztéssel, távoktatással nem hagyományos képzési formákkal javíthatják pozícióikat (Kiss, 2001).

Ellenben a most kialakult járványhelyzetben létrehozott digitális oktatás nem az, ami ezeket a hátrányokat csökkenti. A digitális kompetenciák mellett kiemelném a tanulás tanulása kompetenciát, valamint a reziliencia képességét. Fontos tudnunk, hogy a gyerekek nem egyformán tanulnak, és nem egyformán alkalmazkodnak a megváltozott helyzetekhez sem. A tanulmány eredményeit tekintve elmondható, hogy a gyerekek látszólag ugyan használják a digitális eszközöket, informatika óra keretében sajátítanak el tudást, készséget, azonban eszközhasználatukra jellemző, hogy elsősorban a mobiltelefon és az azon futó alkalmazások gyakoriak, melyek használata közben a szórakozás tölti ki mindennapjaikat.

„A PISA 2012 digitális szövegértéssel és problémamegoldással kapcsolatos felmérésének eredményeiböl kiderül, hogy a magyar tanulók teljesitményük alapján utolsók Európában (Lannert, 2014). Hazai vizsgálatok is megerösítik, hogy a tanulók IKTkompetenciái nem érik el a megfelelö szintet (Fehér, 2014)." (Tóth-Mózer-Kárpáti, 2016: 121)

A hazai COVID-19-járványhelyzet miatt kialakított digitális oktatásra pedig sem a pedagógusok, sem a diákok nem voltak felkészülve. Felmerül a kérdés, hogy ilyen nagy léptékü fejlődés során mennyire vagyunk képesek megfelelően alkalmazni az új technológiák adta lehetőségeket, illetve mennyire korlátoz bennünket ezen eszközök alkalmazása. Erre részben választ kapunk a Digitális oktatási kiáltvány címü írásban:

„A közvélekedéssel ellentétben a fiatal generáció egy jelentős része nem használja készségszinten
a digitális eszközöket, a látszólag folyamatos eszközhasználat gyakran kimerül egyszerü
kommunikációs, közösségi vagy multimédia funkciókban, de gyakran egyszerü eszöobbeállítások
vagy triviálisnak gondolt folyamatok kezelése, adatok keresése, tárolása, rendezése is problémát
okoz. A PISA felmérés Magyarországra vonatkozó részében meglepö eredményeket találunk,
amiből következtetni lehet arra, hogy a jelenlegi oktatási rendszer nem alkalmas arra, hogy a
digitális szövegértést fejlessze, sőt bizonyos szempontból ellentétes hatást fejt ki.” (IVSZ, 2020)

A téma kapcsán fontos, hogy megértsük, agyunk hogyan tud alkalmazkodni a 21. század elektronikus fejlődéséhez, hiszen annak felépítése csak részben képes a technikai fejlődést befogadni, így valódi korlátot jelenthet arra vonatkozóan, hogy ténylegesen mit tudunk vele véghez vinni. Agyunk korlátozott számban képes szociális viszonyainkat kezelni, melyhez ki kellett fejleszteni azt az információfeldolgozó kapacitást, amely képes kezelni és hasznosítani a kapcsolati háló állandó változásait. A nyelv kialakulása a szociális agy fejlődésével hozható összefüggésbe, melynek feladata a kötődés biztosítása, ami a faj sikeres túléléséhez szükséges. A szociális kapcsolataink száma korlátozott, hiszen egy társalgási csoport négy fönél több résztevőtől többel már nem képes működni. Ha ennél nagyobb a csoport, előadásról beszélünk. Ahogy többnyire az előadás során, úgy az elektronikus kommunikációnál is hiányos, vagy nincs a szemtől szembeni interakció. A szociális kompetencia (személyközi és állampolgári kompetencia), melyben döntő szerepe van a nem verbális jelzések felismerésének abban, hogy helyesen tudjuk értelmezni az interakciós partnereink mondandóját, szándékát, az említett kulcskompetenciák egyike. Fontos, hogy megértsük, az e-világ technológiáinak kihasználását az emberi agy alapvető jellemzői korlátozzák. A technika lehet bármennyire is fejlett, az emberi kapcsolatoknak szüksége van a személyes érzelmi kapcsolódásokra, hiszen az emberi kapcsolatok meghittségét a gyakori interakciók teszik erőssé. Ezért szükséges, hogy megtanuljuk ezeket az eszközöket arra használni, amire agyunk természeténél fogva nem képes. 
Azonban amit az offline ,valóságban” megtapasztalunk, azt adaptálnunk kell, mert az egyén a digitális térben eltérően érzékelheti mások érzelmeit, máshogy szabályozza saját és mások viselkedését. Ez az eltérés azonban eredményezhet konfliktushelyzetet. Tudjuk, hogy a telefon használata közben is sokat jelentenek azok a járulékos jelek, melyek a kommunikációnkat kiegészítik és segítik a partnerrel való társalgást (Dunbar, 2006).

Jelenleg Magyarországon az európai tagállamok között az egyik legalacsonyabb az IKT-val támogatott tanórák aránya, amelynek egyik fő oka nem elsősorban a megfelelő technológiai eszközök, hanem a pedagógusok megfelelő képzettségének, motivációjának és támogatásának a hiánya. „A pedagógusok jelenleg inkább a tanitás és nem a tanulás folyamatának gazdagítására használják az informatika által kínált lehetőségeket, továbbá az online térben végzett közös alkotómunka meglehetösen ritka." (Magyarország Digitális Oktatási Stratégiája Kormány-előterjesztés, 2016 :33) Ennek ellenére a pedagógusok egyre inkább elfogadják, hogy a digitális kompetencia fejlesztése közös feladat, nem csak az informatikatanár dolga. A felelősség elismerése mellett megindult a gyakorlati munka is (MDO, 2016).

\section{Iskolai empirikus kutatás: Generációs különbségek az IKT-eszközök használatában}

\section{A kutatás célja}

Mivel a köznevelési intézményekben több korosztály van jelen, az infokommunikációs eszközök használatában meglévő generációs különbségek e színtéren is tükröződnek. További problémaként ehhez hozzájárul az intézmények IKT-eszközökkel való egyenlőtlen ellátottsága. Nem mindegyik iskola van felszerelve a „Z” és az „Alfa” generációnak megfelelő kommunikációs eszközökkel.

Az oktatás módszertana is átalakulóban, de leginkább az a kérdés, hogy milyen módon közvetítse az iskolában a pedagógus az információkat, hogyan tanítson ahhoz, hogy a diákok figyelmét fenn tudja tartani a gyorsuló információáramlás közepette. Ebben nyilvánvalóan segítségére lehet a pedagógusoknak az IKT-eszközpark, ha rendelkezik az iskola a szükséges eszközökkel. Továbbá az eszközök és az információk gyorsasága, a digitális világ és társadalom változása kihívások elé állítja a pedagógusokat, szülőket, így egyre inkább előtérbe kerülnek olyan készségek és képességek, mint a rugalmasság, tudatosság, következetesség, nyitottság, alkalmazkodás (Nikitscher, 2015).

Az általam vizsgált iskolában még tanít a bébibumm generáció, döntően azonban az $\mathrm{X}$, de már megjelennek az Y generáció tagjai is a pedagógusok közt.

A kutatásom célja az volt, hogy megvizsgáljam a diákok és tanáraik infokommunikációs eszközhasználat-eltéréseit, valamint azt, hogy a válaszadók szubjektív megítélése alapján az IKT-eszközök, az internet használata milyen szokásokként determinálódik a mindennapokban. Feltételeztem továbbá, hogy a diákok nem csak játékra, szórakozásra használják az IKT eszközöket, hanem tanulásra is, így a pedagógusokéval hasonló lehet az eszközhasználatuk.

\section{Minta és módszer}

A kutatásom során két kérdőíves felmérést, valamint egy fókuszcsoportos interjút végeztem. Az egyik kérdőívet a tanulók, a másikat a pedagógusok töltötték ki. A kérdőíveket online formában készítettem el, mely tartalmazott zárt és nyitott kérdéseket egyaránt. A vizsgálati minta nem reprezentatív, az eredményekből csupán a mintára nézve lehet következtetéseket levonni. 
A kérdőívben elsősorban, a digitális kommunikációra, illetve az iskolában megjelenő bántalmazásra térek ki, azonban a fókuszcsoportos interjú során a pedagógusok maguk hozták fel a kommunikáció témáját. Jelen írásomban a bántalmazás és zaklatás témakörére nem térek ki.

A kérdőívet Bács-Kiskun megye déli részén fekvő kisvárosban, egy egyházi általános iskolában vettem fel, ahol összesen 29 fö pedagógus és 253 tanuló vesz részt az oktatásban. A diákok közül hátrányos és halmozottan hátrányos helyzetü 70 fó, míg a sajátos nevelésű igényü, beilleszkedési tanulási nehézséggel küzdő gyermekek száma 86 fö. Kérdőívem 52 fő diáknak küldtem el online formában, az összes 7-8. évfolyamon tanuló diák részére, akik közül saját bevallásuk szerint 15\%-uk roma családban él. Velük számítástechnika óra keretében, osztályonként kaptam lehetőséget a kitöltésre, így személyesen is segíthettem a kitöltés menetét.

Az iskola technikai felszereltsége megfelelö, elérhető WIFI-pont, amely a pedagógusok számára rendelkezésre áll. Az iskola a tanulók számára biztosítani tudja a megfelelő számú IKT-eszközt az oktatáshoz, valamint a jó minőségü internetvonalat. WIFI-pont a diákok részére nem biztosított. Okostábla nem minden osztályban érhetö el, összesen 12 darabbal rendelkeznek.

A pedagógusok esetében az iskolától kapott címlista alapján került kiküldésre az ürlap az összes pedagógusnak, akiket személyesen is felkértem a kérdőív kitöltésére. A kérdőívek felvétele elött próbakérdezést készítettem, melynek keretében 5 pedagógust szólítottam meg, akiket egy fókuszcsoportos interjúra is felkértem. Az interjún 4 fö pedagógus vett részt, melyből 2 fö a bébibumm, 2 fö pedig az X generáció tagja. A megadott határidőig a kiküldött 29 pedagógus-kérdőívből 18 érkezett vissza. A visszaérkezett válaszok alapján a pedagógusok generációs megoszlása a következő: $27,8 \%$ a bébibumm; $55,6 \%$ az X, míg 16,7\% az Y generációhoz tartozik. A diákok közül mind az 52 fő kitöltötte a kérdőívet, ők már a Z generáció tagjai.

\section{Eredmények}

A válaszadó pedagógusok, döntően otthonukban interneteznek, háromnegyedük az iskolában is használ internetet, és az eszközhasználatban jellemzően a laptop jelenik meg, míg a tablet és az asztali számítógép egyre kevesebb helyen van jelen. Ennek hátterében véleményem szerint az oktatási rendszerben kapott eszközök játszanak szerepet.

Játéktevékenységre a pedagógusok egyáltalán nem használják sem az internetet, sem az ahhoz kapcsolódó eszközöket (számítógép, PlayStation videojáték-konzol (PS), Xbox videojáték-konzol (Xbox), és mobilnetet a válaszadók közül 5 fő soha nem használ.

A diákok estében a megkérdezettek közül 2 gyermek jelezte, hogy otthon nem rendelkezik internetkapcsolattal, és átlagosan 6-7 éves korukban már használtak valamilyen kommunikációs eszközt. Számomra, a kérdőív egyik nagy meglepetése volt, hogy a gyerekek legfőbb kommunikációs eszköze a mobiltelefon. A várakozásaimmal ellentétben megjelenik ugyan például a PS, vagy az Xbox is, ugyanakkor a használata jelentősen alulmarad az okostelefonnal szemben. Mivel a mobiltelefon hosszú távon nem alkalmas iskolai feladatok elvégzésére, ebből arra következtetek, hogy az iskolai feladatokra nem használják az internetet és az infokommunikációs eszközöket.

A kutatás során a közösségi oldalak megjelenésére is kíváncsi voltam az oktatásban. A kapott válaszok alapján a pedagógusok 16\%-a rendelkezik ugyan Facebook fiókkal, azonban annak használata nem épült be a mindennapjaikba. Feltételezhetően elsődlegesen a szülők 
elérhetősége miatt kerül sor a használatára. A válaszok szerint csak személyes kommunikációra használják, egyéb tartalmakat nem osztottak meg eddig. A bébibumm generáció kis százalékban használja a közösségi oldalt (1 fö), és döntően semmilyen egyéb közösségi oldalon nem regisztráltak, így a diákok számára szánt feladatokat, vagy a szülőkkel való kommunikációt sem az online térben intézik, míg a fiatalabb generációs pedagógusok már esetlegesen feladatokat is adnak a diákjaiknak, a szülöket pedig rendszeresen online módon érik el, amennyiben szükséges. A diákok esetében a Facebook, az Instagramm, a SnapChat, a TikTok és a Youtube térhódítása kiemelkedő. Azonban ezeken a fórumokon döntően a szórakozás az elsődleges felhasználás, nem pedig a tanulás. Azonosságot mutatott mind a diákok, mind a pedagógus által adott válaszok alapján a biztonságos internethasználat. Elmondható, hogy hiányos ismeretekkel rendelkezik mind a két csoport, csak általános információk birtokában vannak a biztonságos internet használatról. A pedagógusok az interjú során arról is beszámoltak, hogy ebben nemcsak a saját és a diákok tudása kevés, de sok esetben a szülő sem elég tudatos és jártas az online jelenlétben, vagy a biztonság tekintetében.

\section{Következtetések}

Tanulmányomban nem a digitális oktatás volt a fő irány, azonban szükségszerüvé vált, hogy említést tegyek róla. A kommunikációs szokások, az eszközhasználat változása kiemelkedően fontossá teszi, hogy mint iskolai szociális munkás foglalkozzak a témával. A generációk közti kommunikációs különbségek javítására, valamint az agresszió és bántalmazás csökkentésére számos jó gyakorlat létezik, melyeket munkám során használhatok. Ilyen módszerek, az „Enable”, a „Békés iskolák” vagy az „Arizona szoba”.

Az iskolai szociális munka feladatköre véleményem szerint lehetővé teszi, hogy a tanulmányban tárgyalt témában eredményesen segítsék a pedagógusokat, a tanulókat és szülőket. Fontos hangsúlyoznunk az iskolai szociális munka megelőző szerepét, hogy a segítség, a probléma kialakulásától jelen lehet az intézményekben, így eredményesebben tud részt vállalni a megoldásukban is. Elsődleges feladatként jelenik meg, hogy az iskolai szociális munkás közelebb hozza egymáshoz az oktatási rendszer szereplöit, és amennyiben eredményesen tud müködni az adott intézményben, úgy kialakulhat egy érzékenyebb iskolai légkör, amely támogatja az iskolai lemorzsolódás megakadályozását is, biztosítva az esélyegyenlőséget. Úgy gondolom, ez komoly kihívást jelent azon a színtéren, ahol újdonságként jelenik meg ez a fajta szociális szemlélet. Véleményem szerint az az iskolai szociális munkás, aki azonosulni tud munkája lényegével, annak értékeivel, megfelelő kiegészítést tud biztosítani az arra nyitott pedagógusok munkájában. Azonban fontos betartani a kompetenciahatárokat, hiszen az iskolai szociális munka határterület (Budai, 2019).

Az iskolai szociális munkásnak ugyan az adománygyüjtés nem feladata, azonban semmi sem tiltja, hogy közösségi gyüjtést szervezzen azon családok számára, akiknél több iskolás korú gyermek van, és korlátozott számban rendelkeznek a digitális oktatásban való részvételhez szükséges eszközökkel, amennyiben az áramellátás és az internethozzáférés biztosított. Feladatkörébe azonban tartozhat, hogy csoportfoglalkozásokat szervezzen és/vagy tartson (amennyiben rendelkezik a szükséges tudással, akár ő maga is) mind a három csoportnak a digitális írástudás területén. A szociális készségfejlesztés pedig egyértelmüen a feladata, mely témakörben úgy gondolom, hogy nagyon sok tennivalója van egy iskolai szociális munkásnak. A szociális prevenciós csoporttevékenység elsősorban a problémás területekre hívja fel a figyelmet, és a veszélyeztetettség megelőzését szolgálhatja. 
Érdemes azonban szem előtt tartani, hogy minden stratégiai megvalósítás során, mint minden kezdeményezéshez, ehhez is szükséges az intézmény vezetésének elkötelezettsége, aktív támogatása. Ezenkívül úgy gondolom - és ezt a fókuszcsoportos interjú során a pedagógusok is megerősítették -, hogy a helyes önismeret elengedhetetlen része a megelőzésnek, és nagymértékben függ a diákok, a pedagógusok kommunikációs és együttmüködési képességének fejlettségétől is.

A tanulói kompetenciafejlesztést szem előtt tartva módosításokra, fokozottabb tervszerüségre és újításokra van szükség, nemcsak az általam vizsgált iskolában, hanem szinte az ország valamennyi oktatási intézményében és akár már az óvodában is. Fontos lenne a meglévő jó gyakorlatokat szélesebb körben terjeszteni, hozzáférhetővé tenni.

Mindezen tevékenységek azonban csak támogatják a köznevelési rendszerben kialakításra és bevezetésre váró új módszereket, amely globális társadalmi és gazdasági szinten is alkalmazkodni képes fiatalokat készít fel az életben a sikeres részvételre, akik képesek a 21. századi folyamatos technológiai fejlődéssel és az infokommunikációs technológiák térhódításával járó változásokra.

\section{Irodalom}

Az egész életen át tartó tanuláshoz szükséges kulcskompetenciák (2009). OFI. https://ofi.oh.gov.hu/tudastar/nemzetkozi-kitekintes/egesz-eleten-at-tarto\#1

Babusik F. (2003). Az esélyegyenlőség korlátai Magyarországon. L’Harmattan Kiadó.

Buda A. (2019). Generációk, társadalmi csoportok a 21. században. Magyar Tudomány, 180(1), 120 129. https://doi.org/10.1556/2065.180.2019.1.12

Budai I. (2019). Az együttműködő iskolai szociális munkás. Párbeszéd, 6(1). https://doi.org/10.29376/parbeszed/2019/1/3

Digitális oktatási kiáltvány (2020). https://ivsz.hu/oktatas/digitalis-oktatasi-kialtvany/

Dunbar, R. I. M. (2006). Vannak-e kognitív korlátai az e-világnak? Világosság, 47(6-7), 149-158.

Kiss M. (2007). A digitális esélyegyenlőség helyzete Magyarországon. Infotars, 7(3), 83-101. http://epa.oszk.hu/01900/01963/00022/pdf/infotars_2007_07_03_083-101.pdf

Klenovitsné Zóka T. (2011). Digitális nemzedék megváltozott pedagóguskompetenciák. PTE BTK.

Komár Z. (2017). Generációelméletek. Új Köznevelés, 73(8-9), 14-16.

Magyarország Digitális Oktatási Stratégiája Kormány-elöterjesztés. 2016. június 30.

Nikitscher P. (2015): Milyen a jó pedagógus? - Elvárások és az érzékelt valóság egy nagymintás diákkutatás eredményei alapján. Educatio, 24(1), 130-139. http://epa.oszk.hu/01500/01551/00071/pdf/EPA01551_ecucatio_2015_1_129-139.pdf

Oktatási rendszerek az új koronavirus járvány idején (2020). Infojegyzet, 2020/10.

Tóth-Mózer Sz. \& Kárpáti A. (2016). A digitális kompetencia kognitív dimenziója és összefüggésrendszere egy empirikus kutatás tükrében. Magyar Pedagógia, 116(2), 121-150.

Varga A. (2013). Az esélyegyenlőség értelmezési kerete. In Varga A. (szerk.), Esélyegyenlöség a mai Magyarországon (pp. 11-15). PTE BTK NTI Romológia és Nevelésszociológia Tanszék.

Varga B. (1999). Manuel Castells és a McLuhan-galaxis halála. JEL-KÉP, (2), 59-67. http://real-j.mtak.hu/5618/2/JelKep_1999_2.pdf

Zombainé Tarnótzky K. (2015). Generációk összehasonlítása, különös tekintettel a Z generáció és tanáraik között fellelhető különbségekre (szakdolgozat). 